\title{
DETERMINATION OF INFLUENCE OF AUXILIARY INGREDIENTS ON ANTIOXIDANT ACTIVITY OF EXTRACT OF LEAVES OF THE QUINCE AND GRAPES SEED MEAL IN PHYTOGEL WITH THE USE OF SPECTROMETRIC METHOD WITH THE DPPH INDICATOR SYSTEM
}

\author{
Elena Kuznetsova \\ Department of Industrial, Clinical Pharmacy and Clinical Pharmacology \\ P. L. Shupyk National Medical Academy of Postgraduate Education \\ 9 Dorogozhitska str., Kyiv, Ukraine, 04112 \\ elena_kuz@i.ua \\ Victoria Butska \\ Department of Industrial, Clinical Pharmacy and Clinical Pharmacology \\ P. L. Shupyk National Medical Academy of Postgraduate Education \\ 9 Dorogozhitska str., Kyiv, Ukraine, 04112 \\ Alexander Tymchenko \\ Department of Industrial, Clinical Pharmacy and Clinical Pharmacology \\ P. L. Shupyk National Medical Academy of Postgraduate Education \\ 9 Dorogozhitska str., Kyiv, Ukraine, 04112 \\ Tetiana Dzhan \\ Department of Microbiology, Modern Biotechnology, Ecology and Immunology \\ Open International University of Human Development "Ukraine" \\ 23 Lvivska str., Kyiv, Ukraine, 03179
}

\footnotetext{
Abstract

To study an impact of auxiliary substances on gel containing extracts of quince leaves and grape seed meal, which is based on polymethylsiloxane.

Pharmaco-technological and physicochemical methods. In this study, a spectrophotometric method is applied to determine an antioxidant activity of the gel.

We examined an impact of auxiliary substances on the gel. According to the results of studies we chose auxiliary ingredients which improve not only gustatory quality but also technological parameters. Applying spectrometric analysis, we investigated an antioxidant activity of phytogel. The gel has a structure of rigid matrix, which is built through a process of condensation of methylsilanetriol and siloxane bonds between the silicon atoms, which makes it possible to maintain and stabilize active natural ingredients. The experiment proved that the extract of leaves of quince and grape seed meal have some antioxidant activity. But, upon the introduction of stevia extract as a coregent taste, the gel that contains quince leaf extract and grape seed meal increases the antioxidant activity. Phytogel has antioxidant activity of $84 \%$ relative to the reference sample, which suggests that the gel can resist the harmful effects of free radicals, which are constantly produced in the human organism.

It was confirmed that the addition of auxiliary substances into the gel with the extracts of quince leaves and grape seed meal based on polymethylsiloxane increases bioavailability and therapeutic efficiency, in particular, the antioxidant activity, of the gel.

Stevia extract as an adjuvant in the phytogel, as gustatory corrector, increases the antioxidant activity of phyto pharmaceutical drugs.

Keywords: antioxidant activity, phytogel, extracts of quince, grape, stevia, ascorbic acid.
}

\section{Introduction}

The question about a formation of the antioxidant index and its use as an objective measure of positive effectiveness of antioxidant substances on human health as well as the indicator of high quality of functional pharmaceutical drugs is widely discussed in many countries [1-3]. 
Therefore analysis of antioxidant properties of natural substances and products, which are based on natural substances, is one of the important concerns nowadays.

Medicinal products with antioxidant properties are used for prevention of diseases caused by excessive quantity of free radicals, formed in human body under the influence of negative external factors $[4,5]$.

The need to update the assortment of domestic phytopreparations including an antioxidant effects is beyond doubt [6]. The modern aspect is a relatively assortment of natural raw materials, caused by high pharmacological activity and expressed clinical effects, among which significant place is occupied by the extract of quince leaf and grape seed meal [7, 8]. As it is known, the main pharmacological effect of the extract of red grapes (leaves, seeds, combs, and bagasse) is the strengthening vascular walls of veins and capillaries (P-vitamin activity). [9]. At present polyphenol complex is contained in the extract of grape seed meal that also has important therapeutic value and a high antioxidant activity [10].

Beyond doubt is the need to use the natural gastroprotective antiulcer medications in the treatment of peptic ulcer disease. This group of drugs directly protects the mucous the stomach from the irritating effects of external factors through the formation of ulcers on the surface of the protective cladding, which promotes scarring and prevents them from exposure to of gastric juice [11].

These substances include antioxidants natural. They regulate the normal activities of the human organism, in particular of oxidation lipid, protein and nucleic acid, resulting in cells which are formed highly active of oxygen compounds called free radicals. They, undoubtedly, show a therapeutic effect, and or other compounds that are contained in natural plants [12].

For example, quince leaves extract inhibits the proliferation of intestinal tumor cells and of renal adenocarcinoma cells [13]. Presence of chlorogenic acid in the extract, together with other antimicrobial determines polyphenolic compounds and antiviral activity. [14] Reported antiulcer activity of extracts of quince fruits on the model of ethanol-induced gastric ulcers [15].

The choice of inactive ingredients is a highly important step in the development of new pharmaceutical medicaments, as they can affect not only on the physical and chemical characteristics of pharmaceutical forms in the process of their production and storage, but also on therapeutic efficiency of the pharmaceutical drug itself [16].

We have selected and studied composition of the gel and proved its biological efficiency in our previous works.

The gel preparation technology is based on stage addition of active pharmaceutical ingredients and inactive ingredients $[17,18]$.

Flavors are important among inactive ingredients because unpleasant taste of pharmaceutical drugs can prevent to take this medicine.

Natural extract of stevia was chosen as a corrective agent.

It was done because of the following reasons: the regular use of stevia extract normalizes carbohydrate and fat metabolism in human body; cell regeneration and blood coagulation are being improved; and the growth of tumors slows down. The sweet secret stevia stevioside, contained in the molecule, which is a glycoside consisting of glucose, sucrose, and steviol of stevia extract is a complex stevioside. Numerous experiments have shown that regular use of an extract from stevia - reduced sugar levels in the blood, cholesterol and radionuclides in the body, improving cell regeneration and blood coagulation, inhibited the growth of tumors [19].

\section{Aim of research}

To determine an influence of auxiliary ingredients on bioavailability and therapeutic effectiveness, especially on antioxidant activity of gel with extract of quince leaves and grape seed meal, which is based on polymethylsiloxane.

\section{Materials and methods}

Researches were conducted when testing samples of the gels, made with similar pharmaceutical structure by means of similar technology [17]. 
At first polymethilsiloxane was dispersed to homogeneity in a separate container at a defined temperature and speed of the rotor mixer.

Measured amount of water, xanthan gum and sorbic acid were injected separately into heated flask.

Flask was heated to a temperature of $60^{\circ} \mathrm{C}$ and mixture of above mentioned ingredients were blended until smooth.

Then the water phase was added to disperse polymethilsiloxane.

The mixture was stirred to obtain phytogel [17].

Further, all extracts were injected to this basis one after another, then they were stirred and afterwards some samples were taken.

Experimental procedure

Testing samples were held at room temperature for 8-12 hours and on their basis we prepared testing samples of $-10 \%$ aqueous solution, which concentration amounts $30 \mathrm{mg} / 100 \mathrm{ml}$ on a dry basis.

Our experimental studies of antioxidant activity were conducted by a modified method [20].

The principle of the method is based on the reduction of stable radical 2 2-diphenyl-1-picrylhydrazyl (DPPH) by antioxidant molecule. The result of this method is to change the optical density of the solution at $515 \mathrm{~nm}[21,22]$.

Antioxidant activity (AOA) is expressed as \% inhibition of DPPH radical, which is represented by the formula:

$$
\% \text { of inhibition }=\left[\left(\mathrm{A}_{0}-\mathrm{A}_{\mathrm{k}}\right) / \mathrm{A}_{0}\right] * 100
$$

where $\mathrm{A}_{0}$ - optical density at $\mathrm{T}=0 \mathrm{~min}$ (solution $\mathrm{DPPH}$ ); $\mathrm{A}_{\mathrm{k}}$ - optical density at $\mathrm{T}=10$ min in the presence of antioxidant.

Measurements were performed on spectrophotometer Hewlett Packard 8452A with layer thickness of $10 \mathrm{~mm}$ cuvettes.

Ascorbic acid, in particular water solution of $30 \mathrm{mg} / 100$, was chosen as a reference standard (reference sample), $\mathrm{ml}$.

\section{Results of research}

Apparently from the chart, addition of gel with extract of leaves of a quince extract of meal of dark grades of grapes increases its antioxidant activity almost in 3 times, and addition of extract of leaves of a stevia leads to increase in antioxidant activity too. The results of research of samples of gel depending on its structure are presented on the chart (Fig. 1).

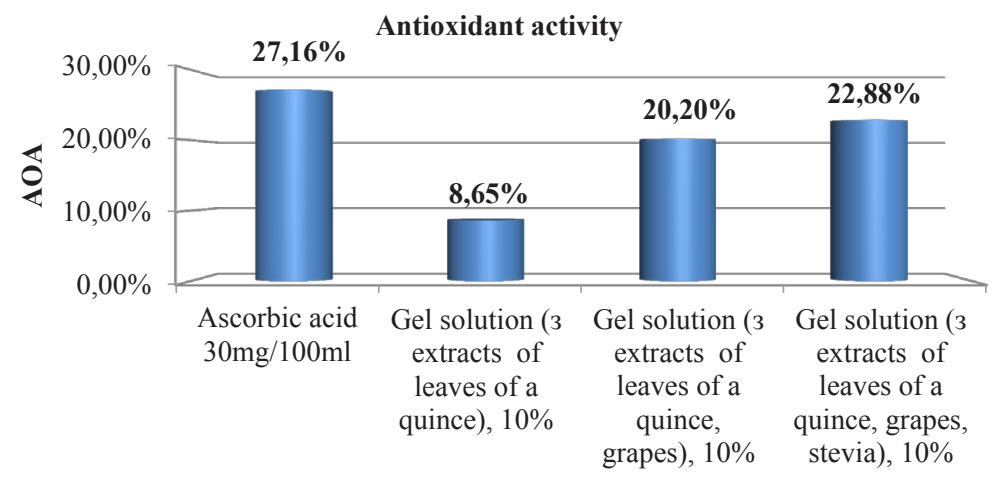

Fig. 1. Antioxidant activity of the gel depending on its composition

Recovery of the free radical DPPH of the gel with participation phenolic compounds from the extracts of leaves and quince seed meal grape kinetically passes slower than in the other two cases (Table 1). This confirms the feasibility of using the gel extract meal of dark grapes and extract of stevia leaves in the composition. 
Results of the examination of gel samples, depending on their composition, are represented in the following table (Table 1).

Table 1

Antioxidant activity indicators

\begin{tabular}{ccccc}
\hline Product name & $\mathbf{A}_{\mathbf{0}}$ & $\mathbf{A}_{\mathbf{k}}$ & $\mathbf{\%}$ AOA & \% AOA relative to control \\
\hline Ascorbic acid & 0,83 & 0,6046 & 27,16 & 100 \\
Gel with quince leaves extract) & 0,8096 & 0,7396 & 8,65 & 74,84 \\
Gel with quince leaves and grape extract & 0,8149 & 0,6503 & 20,20 & 84,24
\end{tabular}

According to results, which are shown in the table, addition of grape seed meal together with addition of stevia extract to an extract of quince leaves tripled the antioxidants activity of the gel.

The results of reduction of free radical DPPH in dynamic are presented graphically in Fig. 2.

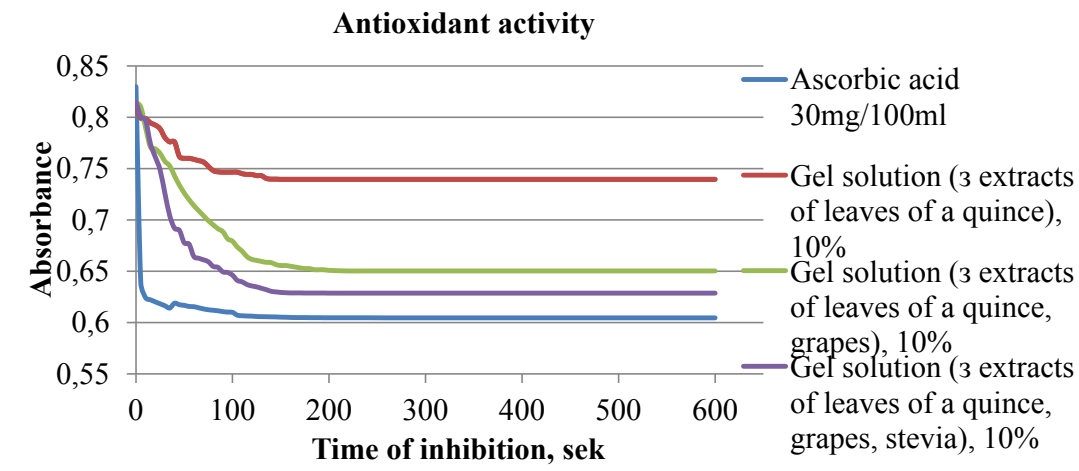

Fig. 2. Comparative antioxidant activity in the dynamic of the DPPH reduction

According to results which are shown in the Fig. 2, each of active ingredients shows antioxidant activity, in a varying degree, but in a complex, these components show higher antioxidant activity in comparison with reference sample.

Thus, the developed composition of gel with extracts of leaves of a quince and meal of grapes on the basis of polymethylsiloxane with excipients, shows the expressed antioxidant activity which on the recovery properties practically does not concede $0,03 \%$ of solution of ascorbic acid.

\section{Discussion}

The study has shown that auxiliary ingredients, namely stevia extract, affect the bioactivity of the gel with extract of quince leaves and grape seed extract, which is based on polymethylsiloxane.

According to the results of the studies was selected technology for producing a gel with extracts of leaves quince and grape seed meal, based on polymethylsiloxane. With spectrometric analysis, we investigated Phytogel on antioxidant activity. The gel has a structure forming a rigid matrix, built through a process of condensation metilsilantriola and siloxane bonds between the silicon atoms, which makes it possible to maintain and stabilize the active natural ingredients. Experiment is proved that of the extract of quince leaves and grape seed meal, have certain antioxidant activity. But at technological introduction stevia extract as auxiliary ingredient is combined with other extracts of the gel to improve the gustatory characteristics, increasing the value of antioxidant activity. Phytogel has antioxidant activity $84 \%$ on reference sample what can confront the damaging effect of free radicals, which are continuously produced in human organism. 


\section{Conclusions}

1. It is established the influence of auxiliary ingredients, namely an extract of stevia, the bioavailability of the gel from the extracts of quince leaf and grape meal based on polymethylsiloxane. It is proved that the antioxidant activity is increased, with the introduction of coregent taste - stevia extract.

2. The spectrometer method with the indicator DPPH system was applied to definition of antioxidant activity of gel from extracts of quince leaves and of meal grapes on the basis of polimethylsiloxane, that gave the chance truly to estimate the select composition of gel at which it is possible to assume that preparations, except antiulcer activity, will show complex therapeutic action on a human organism due to high antioxidant activity.

\section{References}

[1] Shanin, Yu. N., Shanin, V. Yu., Zinov’ev, E. V. (2003). Antioksidantnaya terapiya v klinicheskoy praktike. Saint Petersburg: ELBY, 128.

[2] Mullen, W., Marks, S. C., Crozier, A. (2007). Evaluation of Phenolic Compounds in Commercial Fruit Juices and Fruit Drinks. Journal of Agricultural and Food Chemistry, 55 (8), 3148-3157. doi: 10.1021/ jf062970x

[3] Korovina, N. A., Zakharova, I. N., Skorobogatova, E. V. (2007). Antioksidanty pri obostrenii khronicheskikh gastroduodenitov u detey. Vrach, 9, 79-81.

[4] Khadzhieva, Z. D., Kuznetsov, A. V., Biryukova, D. V. (2012). Tekhnologicheskie aspekti ispol'zovaniya vspomogatel'nykh veshchestv v proizvodstve lekarstvennykh preparatov. Fundamental research, 5, 436-440.

[5] Konkina, I. G., Grabovskij, S. A., Murinov, Yu. I., Kabal'nova, N. N. (2011). Sravnitelnaya otsenka reaktsionnoy sposobnosti kvertsetina i digidrokvertsetina po otnosheniyu k peroksilnyim radikalam. Himiya rastitel'nogo syirya, 3, 207-208.

[6] Spravochnyk lekarstvenykh sredstv, vypusk vos'moy (Hosudarstvennyy ekspertny tsentr MZ Ukrayny) (2015). Available at: http://mozdocs.kiev.ua

[7] Kurkin, V. A., Poroykov, V. V., Kurkina, A. V., Avdeeva, E. V., Pravdivtseva, O. E. (2015). Flavanoidy i lekarstvennyih rasteniy. Prognoz antioksidantnoy aktivnosti. Sovremennyie problem i nauki i obrazovaniya, 2. Available at: https://www.science-education.ru/ru/article/view?id=23252

[8] Kondratev, D. V., Scheglov, N. G. (2009). Sposobyi polucheniya ekstrakta vinogradnyih vyizhimok i vozmozhnosti ego ispolzovaniya v pischevoy promyishlennosti. Izvestiya vysshih uchebnyh zavedenij. Pishchevaya tekhnologiya. 1, 62-65.

[9] Dixon, R. A., Pasinetti, G. M. (2010). Flavonoids and Isoflavonoids: From Plant Biology to Agriculture and Neuroscience. Plant Physiology, 154 (2), 453-457. doi: 10.1104/pp.110.161430

[10] Yashin, Ya. I., Ryizhnev, V. Yu., Yashin, A. Ya., Chernousova, N. I. (2008). Prirodnyie antioksidantyi - nadezhnaya zaschita cheloveka ot opasnyih bolezney i stareniya. Moscow: NPO «Himavtomatika», 122 .

[11] Dronova, M. A., Kiseleva, T. L., Smirnova, Yu. A. (2010). Sovremennyie preparatyi rastitelnogo proishozhdeniya dlya regulyatsii motornoy funktsii zheludochno-kishechnogo trakta. II Rossijskij fitoterapevticheskij s"ezd. Moscow, 32-35.

[12] Lutskiy, M. A., Kuksova, T. V., Smelyanets, M. A., Lushnikova, Yu. P. (2014). Svobodnoradikal'noe okislenie lipidov i belkov - universalnyiy protsess zhiznedeyatelnosti organizma. Uspehi sovremennogo estestvoznaniya, 12-1, 24-28.

[13] Carvalho, M., Silva, B. M., Silva, R., Valentao, P., Andrade, P. B., Bastos, M. L. (2010). First Report on Cydonia oblonga Miller Anticancer Potential: Differential Antiproliferative Effect against Human Kidney and Colon Cancer Cells. Journal of Agricultural and Food Chemistry, 58 (6), 3366-3370. doi: 10.1021/ jf903836k

[14] Fattouch, S., Caboni, P., Coroneo, V., Tuberoso, C. I. G., Angioni, A., Dessi, S. (2007). Antimicrobial Activity of Tunisian Quince (Cydonia oblongaMiller) Pulp and Peel Polyphenolic Extracts. Journal of Agricultural and Food Chemistry, 55 (3), 963-969. doi: 10.1021/jf062614e 
[15] Hamauzu, Y., Inno, T., Kume, C., Irie, M., Hiramatsu, K. (2006). Antioxidant and Antiulcerative Properties of Phenolics from Chinese Quince, Quince, and Apple Fruits. Journal of Agricultural and Food Chemistry, 54 (3), 765-772. doi: 10.1021/jf052236y

[16] Tarahovskiy, Yu. S., Kim, Yu. A., Abdrasilov, B. S., Muzafarov, E. N. (2013). Flavonoidyi: biohimiya, biofizika, meditsina. Puschino: Synchrobook, 310.

[17] Kuznyetsova, O. V., Buts'ka, V. Ye., Dzhan, T. V., Tymchenko, O. H. (2015). Obgruntuvannya rozrobky skladu ta doslidzhennya fizykokhimichnykh vlastyvostey helyu z ekstraktiv lystya ayvy y shrotu vynohradu na osnovi polimetylsyloksanu. Farmatsevtychnyy zhurnal, 4, 30-36.

[18] Kuznetsova, O. V., Lavrenchuk, G. Y., Buts'ka, V. E., Simonova, I. V. (2015). Farmakobiologichni vlastivosti ekstraktu shrotu temnikh sortiv vinogradu Farmakologiya ta likarska toksikologiya, 3, 70-75.

[19] Lyakhovkin, A. G., Nikolaev, A. P., Uchitel', V. B. (1999). Steviya - medovaya trava, rastenie lekarstvennoe i pishchevoe v vashem dome. Saint Petersburg, 96.

[20] Paulova, H., Bochorakova, H., Taborska, E. (2004). Metody stanoveni antioxidacni aktivity prirodnych latek in vitro. In Chemicke listy, 98 (4), 147-179.

[21] Vlasova, I. V., Vershinin, V. I., Tsyupko, T. G. (2011). Metodologiya spektrofotometricheskogo analiza smesey organicheskih soedineniy. Problema neadditivnosti svetopogloscheniya. Journal of Analytical Chemistry, 66 (1), 25-33.

[22] Yashin, Ya. I., Yashin, A. Ya. (2009). Problema opredeleniya soderzhaniya antioksidantov. Metrologiya, 8, 50-53. 